ABDI: Jurnal Pengabdian dan Pemberdayaan Masyarakat ISSN: 2656-369X (Print), 2684-8570 (Online)

Volume 3 No. 1, Juni 2021

http://abdi.ppj.unp.ac.id/index.php/abdi

Email: abdi@ppj.unp.ac.id

DOI: https://doi.org/10.24036/abdi.v3il.79

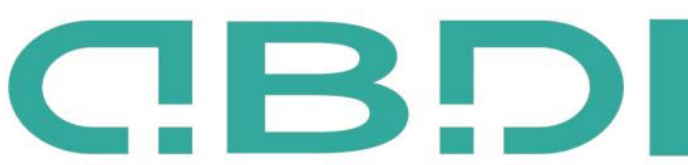

ABDI: JURNAL PENGABDIAN DAN PEMBERDAYAAN MASYARAKAT

\title{
Model In-On Service Training Pengembangan Bahan Ajar PPKn Berbasis Living Values Education Bagi Guru-Guru PPKn
}

\author{
Kokom Komalasari ${ }^{1}$, Rahmat Rahmat ${ }^{2}$, Diana Noor Anggraini ${ }^{3}$ \\ ${ }^{1,2}$ Departemen Pendidikan Kewarganegaraan, Universitas Pendidikan Indonesia \\ ${ }^{3}$ Program Studi Pendidikan IPS, Universitas Pendidikan Indonesia \\ E-mail: kokom@upi.edu $, \underline{\text { rahmat @upi.edu }}, \underline{\text { diana.anggraini@upi.edu }}$
}

\begin{abstract}
Abstrak
Kegiatan ini dilatarbelakangi hasil need assessment guru PPKn, dimana guru memerlukan peningkatan kemampuan teoritis dan praktis pengembangan bahan ajar berbasis nilai karakter, dan perlunya pemanfaatan hasil penelitian dosen (inovasi pembelajaran, kependidikan dasaran, strategis nasional, dan hibah kompetensi) untuk meningkatkan kemampuan teoritis dan praktis guru SMP dalam mengembangkan bahan ajar PPKn berbasis living values education untuk pengembangan peserta didik. Tujuan kegiatan pengabdian adalah meningkatkan kemampuan guru dalam : a) memahami bahan ajar PPKn berbasis living values education; b) mengembangkan bahan ajar PPKn berbasis living values education, dan c) menggunakan bahan ajar PPKn berbasis living values education. Kegiatan pengabdian menggunakan pendekatan in-on service training dengan sasaran guru-guru PPKn SMP di Kota dan Kabupaten Tasikmalaya yang tersebar di 39 Kecamatan (diwakili 78 guru). Produk pengabdian ini adalah desain dan perangkat model In-On Service Training Pengembangan Bahan Ajar PPKn Berbasis Living Values Education, artikel jurnal nasional/internasional dan HKI. Hasil pelatihan pengembangan media pembelajaran Sejarah dilaksanakan secara daring dengan tahap IN-ON service. Pelatihan ini diikuti oleh 78 peserta yang berasal dari Kota dan Kabupaten Tasikmalaya. Narasumber memilih materi yang dipaparkan di antaranya : Pembuatan bahan ajar PPKn berbasis Living Values Education; Pemanfaatan Media Pembelajaran PPKn di Era Digital; Kreativitas Guru dalam Merancang Bahan Ajar PPKn, dan Pembuatan dan Pemanfaatan Bahan Ajar Digital PPKn. Setelah dilakukan pelatihan daring, maka selanjutnya peserta melakukan tugas mandiri yakni praktik media pembelajaran di kelas secara mandiri. Adapun evaluasi pelatihan yang dilakukan adalah evaluasi proses pelatihan, evaluasi hasil pelatihan, dan monitoring evaluasi.
\end{abstract}

Kata kunci: Bahan Ajar; Guru; In-On Service Training; Living Values Education; PPKn.

\section{Abstract}

This activity is motivated by the results of the PPKn teacher's need assessment, where teachers need to improve theoretical and practical skills in developing teaching materials based on character values, and the need to use lecturers' research results (learning innovation, basic education, national strategic, and competency grants) to improve theoretical and practical abilities Junior high school teachers in developing PPKn teaching materials based on living values education for the development of students. The purpose of the service activities is to improve the ability of teachers in: a) to understand PPKn teaching materials based on living values education; $b$ ) developing Civics teaching materials based on living values education, and c) using PPKn teaching materials based on living values education. Community service activities use an in-on service training approach with the target of Civics teachers in Tasikmalaya Regency which are spread across 39 districts (represented by 78 teachers). The product of this service is the design and model of In-On Service Training for PPKn Teaching Materials Development Based on Living Values Education, national / international journal articles and IPR. The results of the training in the development of History learning media are carried out online with the IN-ON service stage. This training was attended by 78 participants from the City and District of Tasikmalaya. The resource persons selected the materials presented, including: Making PPKn teaching materials based on Living Values Education; Utilization of Civics Learning Media in the Digital Age; Teacher Creativity in Designing Civics Teaching Materials, and Making and Utilizing PPKn Digital Teaching Materials. After the online training is carried out, the participants then carry out independent tasks, namely the practice of learning media in class independently. The training evaluation carried out is evaluation of the training process, evaluation of training results, and monitoring evaluation.

Key Word: Civic Education; In-On Service Training; Learning Material; Living Values Education; Teacher. 
Kokom Komalasari, Rahmat Rahmat, Diana Noor Anggraini Model In-On Service Training Pengembangan Bahan Ajar PPKn Berbasis Living Values Education Bagi Guru-Guru PPKn

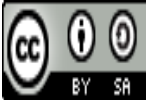

\section{Pendahuluan}

Pendidikan di Indonesia mengalami perkembangan yang cukup pesat dari tahun ke tahun. Pemerataan pendidikan dilakukan di berbagai daerah guna menghasilkan lulusan yang berkualitas. Tidak hanya itu, kesempatan bagi beberapa anak yang ingin bersekolah pun mendapatkan bantuan melalui program bantuan pemerintah. Hal ini menunjukkan bahwa impian generasi muda untuk terus melanjutkan pendidikannya pada jenjang lebih tinggi mendapatkan keniscayaan baru. Begitu pula tenaga pendidik yang selalu berupaya mengasah kompetensi diri untuk mendukung pembelajaran dan hasil belajar. Sebagian kecil daerah Kota Tasikmalaya, jika diperhatikan rasio guru dengan peserta didik, khususnya di SMP sebagai sasaran/subjek kegiatan pengabdian ini, maka ditemukan bahwa rasio guru-peserta didik SMP di kabupaten Tasikmalaya adalah 1:14. Rasio tersebut menunjukkan angka ideal untuk keberhasilan pendidikan di SMP. Tentunya kuantitas guru SMP yang memadai, harus diikuti dengan kualitas kompetensi yang memadai \& memenuhi standar, baik kompetensi professional, kompetensi pedagogic, kompetensi kepribadian, dan kompetensi sosial.

Tabel 1. Angka Partisipasi Sekolah peserta didik pada jenjang SD, SMP, SMA, dan PT di Kota dan Kabupaten Tasikmalaya Tahun 2016/2017

\begin{tabular}{ccccccccc}
\hline \multirow{2}{*}{$\begin{array}{c}\text { Kabupaten/ } \\
\text { Kota }\end{array}$} & \multicolumn{4}{c}{ Kelompok Umur } & \multicolumn{4}{c}{ Kelompok Umur } \\
\cline { 2 - 9 } & $7-12$ & $13-15$ & $16-18$ & $19-24$ & $7-12$ & $13-15$ & $16-18$ & $19-24$ \\
\hline $\begin{array}{c}\text { Provinsi Jawa } \\
\text { Barat }\end{array}$ & $\mathbf{9 9 , 3 0}$ & $\mathbf{9 2 , 8 4}$ & $\mathbf{6 5 , 4 8}$ & $\mathbf{1 9 , 2 7}$ & $\mathbf{9 9 , 5 7}$ & $\mathbf{9 3 , 1 9}$ & $\mathbf{6 5 , 7 2}$ & $\mathbf{1 9 , 4 0}$ \\
$\begin{array}{c}\text { Kota dan } \\
\text { Kabupaten } \\
\text { Tasikmalaya }\end{array}$ & 99,25 & 95,68 & 62,63 & 17,59 & 99,79 & 94,23 & 72,26 & 15,31 \\
\hline & & & & & & & & \\
\hline
\end{tabular}

Sumber: Kota dan Kabupaten Tasikmalaya Dalam Angka Tahun 2017(Pemerintah Daerah Kota Tasikmalaya, 2017)

Berdasarkan data pada tabel 1, maka pada jenjang SMP tingkat partisipasi peserta didik kabupaten Tasikmalaya tahun 2016 berada di atas rata-rata Provinsi Jawa Barat. Sementara pada jenjang lainnya di bawah rata-rata Provinsi Jawa Barat. Tetapi pada tahun 2017 terjadi peningkatan, dimana APS jenjang SD, SMP, dan SMA berada di atas rata-rata Provinsi Jawa Barat, kecuali pendidikan tinggi. Hal ini menunjukkan bahwa di Kabupaten Tasikmalaya pada jenjang pendidikan SMP partisipasi peserta sangat tinggi.

Merujuk pada tingkat partisipasi sekolah penduduk Tasikmalaya berdasarkan analisis isu strategis Dinas Pendidikan Kota Tasikmalaya dalam angka 2017 maka diketahui terdapat beberapa faktor, yaitu: 1) Ketersediaan sarana prasarana pendukung pendidikan seperti perpustakaan, laboratorium, dan bengkel kerja masih terbatas; 2) Selain ketersediaan ruang kelas yang belum memadai, kualitas ruang kelas sendiri belum sepenuhnya ideal. Ruang kelas dalam kondisi rusak berat tingkat SD/MI, SMP/MTs dan SMA/SMK/MA; 3) Kurikulum yang diterapkan di sekolahsekolah belum optimal dalam pembentukan karakter peserta didik yang beriman, bertakwa kepada Tuhan Yang Maha Esa, berakhlak mulia, sehat, berilmu, cakap, kreatif, mandiri dan menjadi warga negara yang demokratis serta bertanggungjawab, dan 4) Pembiayaan melanjutkan pendidikan ke jenjang SMA/SMK/MA masih relatif belum terjangkau oleh semua kalangan. Di sisi lain, kompetensi pendidik pun mempengaruhi tingkat partisipasi sekolah penduduk Tasikmalaya dimana kualifikasi tenaga pendidik belum seluruhnya memenuhi standar. Masih terdapat guru yang ijazah terakhirnya setingkat SMA sebanyak 1.247 orang $(12,94 \%)$ dari 9.639 orang pada tahun 2014 .

Berdasarkan data tersebut di atas, maka Kabupaten Tasikmalaya memiliki potensi untuk pengembangan pendidikan. Jumlah guru yang cukup besar merupakan potensi untuk peningkatan 
Kokom Komalasari, Rahmat Rahmat, Diana Noor Anggraini Model In-On Service Training Pengembangan Bahan Ajar PPKn Berbasis Living Values Education Bagi Guru-Guru PPKn

kuantitas dan kualitas pendidikan. Profesionalisme guru harus terus dikembangkan, diantaranya melalui kegiatan pendidikan dan pelatihan. Realita di lapangan menunjukkan bahwa pada umumnya guru masih memiliki kesulitan dalam mengembangkan kompetensi pedagogik, diantaranya dalam memahami dan mengembangkan media pembelajaran berbasis TIK dan berbasis nilai sesuai tuntutan Kurikulum 2013 untuk meningkatkan kompetensi siswa (pengetahuan, sikap, dan keterampilan siswa). Kendala ini disebabkan diantaranya karena kurangnya pendidikan dan pelatihan yang efektif untuk pengembangan profesionalisme guru. Oleh karena itu, perlu adanya kerjasama Dinas Pendidikan Kabupaten dengan MGMP dan Perguruan Tinggi pencetak guru (LPTK) dalam meningkatkan profesionalisme guru.

Hasil studi pendahuluan dalam bentuk training need assessment guru-guru PPKn yang tergabung dalam wadah MGMP PPKn SMP di Kota Tasikmalaya tahun 2018, diperoleh beberapa kebutuhan guru PPKn untuk meningkatkan kompetensi pedagogis sebagai berikut:

\section{Tabel 2. Hasil Training Need Assessment terhadap Peningkatan Kompetensi Pedagogis Guru} PPKn SMP Kota Tasikmalaya

\begin{tabular}{clc} 
No & \multicolumn{1}{c}{ Kompetensi Pedagogis yang perlu dikembangkan } & $\begin{array}{c}\text { Frekuansi (\%) } \\
\text { N = 50 }\end{array}$ \\
\hline 1 & $\begin{array}{l}\text { Mengembangkan bahan ajar PPKn berbasis nilai karakter sesuai } \\
\text { tuntutan kurikulum 2013 }\end{array}$ & 29 \\
\hline 2. & $\begin{array}{l}\text { Mengembangkan metode pembelajaran PPKn yang secara } \\
\text { komprehensif mencapai kompetensi pengetahuan, sikap, dan } \\
\text { keterampilan kewarganegaraan siswa }\end{array}$ & 20 \\
\hline 3. & $\begin{array}{l}\text { Mengembangkan media pembelajaran kreatif berbasis nilai untuk } \\
\text { pencapaian kompetensi sikap (karakter) }\end{array}$ & 16 \\
\hline 4. & $\begin{array}{l}\text { Memanfaatkan sumber belajar PPKn kontekstual (masyarakat dan } \\
\text { lembaga pemerintah) }\end{array}$ & 20 \\
\hline 5. & Mengembangkan assessment autentik dalam pembelajaran PPKn & 20 \\
\hline
\end{tabular}

Sumber: Training Need Assessment Guru PKn Kota Tasimalaya (Komalasari:2018)

Tabel di atas menunjukkan bahwa hampir semua komponen pembelajaran PPKn perlu dikembangkan, tetapi jika dilihat dari persentase, maka kemampuan mengembangkan bahan ajar PPKn yang kreatif untuk pencapaian kompetensi sikap (karakter) peserta didik memiliki persentase yang paling tinggi (29\%), sehingga untuk tahap pertama perlu upaya peningkatan kemampuan mengembangkan media pembelajaran PPKn berbasis nilai di kalangan guru PPKn SMP di Kabupaten Tasikmalaya.

Hal ini secara rasional didukung dengan beberapa masalah mendasar dalam pengembangan bahan ajar PPKn selama ini di persekolahan yang teridentifikasi melalui focus group discussion dengan MGMP PPKn SMP Kota dan Kabupaten Tasikmalaya sebagai berikut:

a. Kurang memanfaatkan bahan ajar kontekstual berbasis nilai-nilai kehidupan, karena terlalu berorientasi pada buku teks pelajaran PPKn.

b. Bahan ajar yang dikembangkan guru hanya berorientasi pada aspek pengetahuan kewarganegaraan, sedangkan aspek kompetensi sikap dan kecakapan kewarganegaraan terabaikan.

c. Bahan ajar yang dikembangkan guru lebih pada handout yang bersumber dari buku teks, buku referensi, dan lainnya dari internet.

d. Masih sulitnya guru PPKn mengembangkan bahan ajar berbasis nilai dalam bentuk multimedia dengan memanfaatkan sumber kontekstual yang tersedia dan teknologi yang dikuasai.

Oleh karena itu, untuk mengatasi permasalahan guru PPKn dalam pengembangan bahan ajar berbasis nilai perlu diterapkan hasil penelitian terkait dengan integrasi living values education dalam pembelajaran, dengan focus pada bahan ajar. Sehingga hasil penelitian lebih bermanfaat bagi khlayak 
Kokom Komalasari, Rahmat Rahmat, Diana Noor Anggraini Model In-On Service Training Pengembangan Bahan Ajar PPKn Berbasis Living Values Education Bagi Guru-Guru PPKn

pengguna di lapangan/persekolahan dalam memecahkan masalah dan memberdayakan guru PPKn, meningkatkan relevansi keilmuan pendidikan kewarganegaraan yang dikembangkan UPI dengan kebutuhan guru di lapangan dan meningkatkan penerapan integrasi karakter dalam pembelajaran sesuai tuntutan Kurikulum 2013 dalam bentuk bahan ajar PPKn berbasis living values education dalam pembelajaran PPKn. Komalasari, dkk (2011-2018) melalui beberapa Research and Development telah mengembangkan model pembelajaran PPKn kontekstual berbasis living values activity di SMP, dimana salah satu komponen yang dikembangkan adalah bahan ajar berbasis living values activity. Hasil penelitian menunjukkan pengaruh signifikan penerapan living values activity dalam pembelajaran PPKn terhadap pengembangan karakter peserta didik sebesar 43,2\%.

Universitas Pendidikan Indonesia sebagai pencetak calon guru profesional memiliki peran strategis untuk melaksanakan pengabdian kepada masyarakat dalam bentuk pelatihan profesionalisme guru dengan berbasis hasil penelitian dosen. Universitas Pendidikan Indonesia memiliki program pengembangan dosen di bidang penelitian sesuai roadmap penelitian untuk membangun kepakaran bidang ilmu. Hasil penelitian dosen akan lebih bermakna, jika didiseminasikan dan diterapkan kepada guru-guru di persekolahan. Dengan demikian dosen dapat melaksanakan kegiatan Tri Dharma perguruan tinggi dalam penelitian dan pengabdian kepada masyarakat, dan sekaligus kepakaran dosen bermanfaat untuk pengembangan profesionalisme guruguru di persekolahan yang berdampak pada peningkatan komptensi siswa. Oleh karena itu perlu dilakukan kegiatan Pengabdian kepada Masyarakat berbasis Hasil Penelitian melalui model In-On Service Training Bahan Ajar PPKn berbasis Living Values Activity bagi Guru PPKn SMP Kabupaten Tasikmalaya.

Berdasarkan latar belakang masalah yang teridentifikasi di lapangan dan hasil penelitian dalam bidang pembelajaran PPKn berbasis living values education, maka perlu dilakukan "In-On Service Training Pengembangan Bahan Ajar PPKn Berbasis Living Values Education Bagi Guru PPKn SMP Kabupaten Tasikmalaya. Rumusan masalah yang diajukan sebagai berikut: (1) Bagaimana meningkatkan pemahaman guru PPKn SMP Kabupaten Tasikmalaya terhadap Bahan Ajar PPKn berbasis living values education melalui In-On Service Training. (2) Bagaimana meningkatkan kemampuan praktis guru PPKn SMP Kabupaten Tasikmalaya dalam mengembangkan bahan ajar PPKn berbasis living values education melalui In-On Service Training. (3) Bagaimana meningkatkan kemampuan praktis guru PPKn SMP Kabupaten Tasikmalaya dalam menerapkan bahan ajar PPKn berbasis living values education In-On Service Training.

\section{Metode Pelaksanaan}

Kegiatan pengabdian kepada masyarakat dilakukan dalam bentuk kegiatan pelatihan (Training). Nadler dan Wiggs (dalam Robinson \& Robinson, 1989) mendefinisikan pelatihan (training) sebagai teknik-teknik yang memusatkan pada belajar tentang ketrampilan-ketrampilan, pengetahuan dan sikap-sikap yang dibutuhkan untuk memulai suatu pekerjaan atau tugas-tugas atau untuk meningkatkan kemampuan dalam melakukan suatu pekerjaan atau tugas (Robinson \& Robinson, 1989). Hal senada juga dikemukakan oleh Clark (1991) bahwa pelatihan adalah suatu upaya untuk melakukan perubahan dalam hal pengetahuan, ketrampilan-ketrampilan dan sikap (Clark, 1991).

Dalam konteks dunia kerja (guru), maka para peserta suatu pelatihan umumnya adalah orang dewasa, sehingga perlu dikembangkan pendekatan pelatihan yang mendasarkan pada prinsip-prinsip belajar pada orang dewasa (adult learning) yaitu pendekatan pelatihan yang berpusat pada peserta (participant centered training). Pendekatan participant centered training yang digunakan mengacu kepada Pike (2005)(Pike, 2005). Dalam pelatihan dengan Pendekatan participant centered training, para peserta itu sendiri yang seharusnya menjadi pusat perhatian. Artinya, pesertalah yang sesungguhnya mengetahui apa kebutuhan belajar mereka, bagaimana cara belajar yang lebih tepat bagi mereka, untuk bisa memecahkan masalah-masalah yang mereka hadapi. Dalam pendekatan ini, seorang trainer menyediakan lingkungan yang mendukung bagi peserta untuk mengeksplorasi, berjuang dan menjelajahi pikirannya, sehingga mereka memperoleh insight yang nyata, sesuai dengan masalah mereka.

ABDI: Jurnal Pengabdian dan Pemberdayaan Masyarakat Vol. 3 No. 1 
Kokom Komalasari, Rahmat Rahmat, Diana Noor Anggraini Model In-On Service Training Pengembangan Bahan Ajar PPKn Berbasis Living Values Education Bagi Guru-Guru PPKn

Pelatihan dilaksanakan dengan menggunakan desain waktu melalui model in-on service training. Hal ini didasari pemikiran bahwa desain waktu pelatihan adalah faktor penting dalam menentukan efektifitas sebuah pelatihan. Desain program pelatihan seperti ini disebut dengan 'oneshot' strategies. Akan tetapi, menurut Mirici (2006), desain pelatihan one-shot strategy ini kurang efektif dibandingkan dengan 'ongoing programme'. "Ongoing programmes are generally considered more fruitful and effective in achieving the desired objective than one-shot teacher training programs"(Mirici, 2006). Sejalan dengan ini, CERI/ Centre for Educational Research and Innovation (1982:54) sependapat bahwa "most in-service training is "ineffective because it is frequently based on one-shot workshops involving a large or in any case undifferentiated group of teachers, and provides limited time for teachers to learn"(CERI, 1982). Dengan kata lain, pelatihan singkat dengan jangka waktu tertentu dianggap kurang efektif karena desain pelatihan seperti ini membatasi kesempatan belajar guru.

Model in-on service training ini dilengkapi dengan evaluasi pelatihan dan program tindak lanjut. Hal ini dikarenakan pelatihan yang tidak disertai dengan evaluasi dan program tindak lanjut merupakan salah satu penyebab sebuah pelatihan dapat dikategorikan sebagai pelatihan yang tidak efektif. Balchin, et.al. (2006), menegaskan bahwa kebanyakan evaluasi pelatihan yang dilakukan hanya berkisar pada pengukuran hal-hal teknis seperti tingkat kepuasan peserta terhadap materi pelatihan atau pelatih/narasumber. Evaluasi juga harus dilakukan untuk mengukur tingkat pembelajaran peserta dan perubahan tingkah laku peserta sebagai akibat dari hasil pelatihan(Balchin, Randall, \& Tunner, 2006).

Khalayak peserta pelatihan adalah guru-guru mata pelajaran Pendidikan Pancasila dan Kewarganegaraan pada Sekolah Menengah Pertama (SMP) di Kabupaten dan Kota Tasikmalaya. Jumlah SMP/MTs di Kabupaten Tasikmalaya baik di SMP Negeri dan SMP Swasta yang tersebar di 39 kecamatan. Untuk efektivitas dan efisiensi kegiatan pengabdian peserta diambil 2 orang mewakili setiap kecamatan, sehingga jumlah peserta adalah 78 orang.

\section{Hasil Dan Pembahasan}

\subsection{Bahan Ajar Berbasis Living Values Education}

Pelatihan bahan ajar berbasis living values education dilaksanakan secara daring. Beberapa diskusi dilakukan membahas hasil penelitian yang pernah dilakukan peneliti sebelumnya dan diaplikasikan oleh guru-guru di sekolah. Berdasarkan hasil penelitian Komalasari dkk. (2011-2018), khususnya dalam pengembangan bahan ajar PPKn berbasis living values education sebagai salah satu komponen pembelajaran yang memiliki peranan penting. Pengembangan bahan ajar PPKn berbasis living values education tidak akan dapat dilepaskan dari praktek model pembelajaran, sehingga dalam sajian ini dibahas hasil penelitian terkait dengan model pembelajaran berbasis living values education dan hasil penelitian bahan ajar PPKn berbasis living values education untuk pengembangan karakter peserta didik (Komalasari \& Syaifullah, 2011) (Komalasari, Bestari, \& Haryasa, 2012) (Komalasari, Saripudin, \& Masyitoh, 2013) (Komalasari, Saripudin, \& Masyitoh, 2014) (Komalasari, Saripudin, \& Masyitoh, 2015) (Komalasari, Saripudin, \& Masyitoh, 2016) (Komalasari \& Saripudin, 2017) (Komalasari, Abdulkarim, \& Saripudin, 2018).

Bahan ajar PPKn berbasis living values education secara konseptual adalah integrasi nilai-nilai kehidupan (living values) dan prinsip-prinsip living values education ke dalam bahan ajar dengan memperhatikan prinsip pembelajaran saintifik (tuntutan pembelajaran dalam Kurikulum 2013), mengembangkan Kompetensi Inti dan Kompetensi Dasar sesuai kurikulum 2013, prinsip-prinsip penyusunan materi/bahan ajar, bahasa dan keterbacaan, dan penampilan (grafika).

Berdasarkan hal tersebut, maka diperoleh beberapa prinsip penulisan bahan ajar berbasis living values education (Tillman, 2004) (Komalasari, Saripudin, \& Iswandi, 2016) sebagai berikut:

1) Mengembangkan nilai-nilai kehidupan, meliputi: Kedamaian, Penghargaan, Cinta, Tanggung jawab, Kebahagiaan, Kerja sama, Kejujuran, Kerendahan hati, Toleransi, Kesederhanaan, Kebebasan dan Persatuan 
Kokom Komalasari, Rahmat Rahmat, Diana Noor Anggraini Model In-On Service Training Pengembangan Bahan Ajar PPKn Berbasis Living Values Education Bagi Guru-Guru PPKn

2) Mengembangkan prinsip-prinsip living values education (Tillman, 2004: xv) yang meliputi: a) Menghimpun butir-butir refleksi; b) berimajinasi secara luas; c) melatih relaksasi dan focus; d) mengekspresikan kreasi seni; e) mengembangkan keterampilan social; f) mengembangkan kesadaran kognitif tentang keadilan; g) mengembangkan kerukunan social; dan h) menghimpun nilai-nilai budaya.

3) Menerapkan prinsip pembelajaran dalam penulisan bahan ajar, yang meliputi: a) Kesiapan (Readiness); b) Motivasi; c) Penggunaan alat pemusat perhatian (ilustrasi, gambar warna warni, tulisan bervariasi); d) Partisipasi aktif peserta didik; e) Perulangan; f) Umpan balik; g) Visi interaksi sosial kognitif; h) Authentic assessment; i) Refleksi; j) Life skill; k) pengamatan, bertanya, mengumpulkan informasi, menganalisis, dan mengomunikasikan; dan 1) Model pembelajaran projek, pemecahan masalah, dan penemuan.

4) Mengembangkan kompetensi inti dan kompetensi dasar dalam kurikulum 2013, yang meliputi: a) membentuk pengetahuan; b) keterampilan; dan c) sikap.

5) Memperhatikan prinsip-prinsip penyusunan materi/bahan ajar, yaitu: a) akurat, materi hendaknya akurat dan benar ditinjau dari segi keilmuan; b) Relevan; c) Cukup memadai; d) Konsisten; e) Aktual; dan f) Struktur keilmuan, urutan penyajian (sequence) materi sesuai dengan struktur keilmuan setiap mata pelajaran.

6) Bahasa dan keterbacaan disusun dengan memenuhi kriteria: a) Kalimat yang digunakan sesuai dengan kaidah bahasa Indonesia yang baik dan benar; b) Susunan kalimat hendaknya menunjukkan pola berpikir logis dan sistematis; c) Struktur kalimat sesuai dengan tingkat penguasaan bahasa peserta didik; d) Kalimat yang digunakan komunikatif.

7) Penampilan bahan ajar (Grafika) dibuat dalam: a) Format; dan b) Ilustrasi gambar dan tabel.

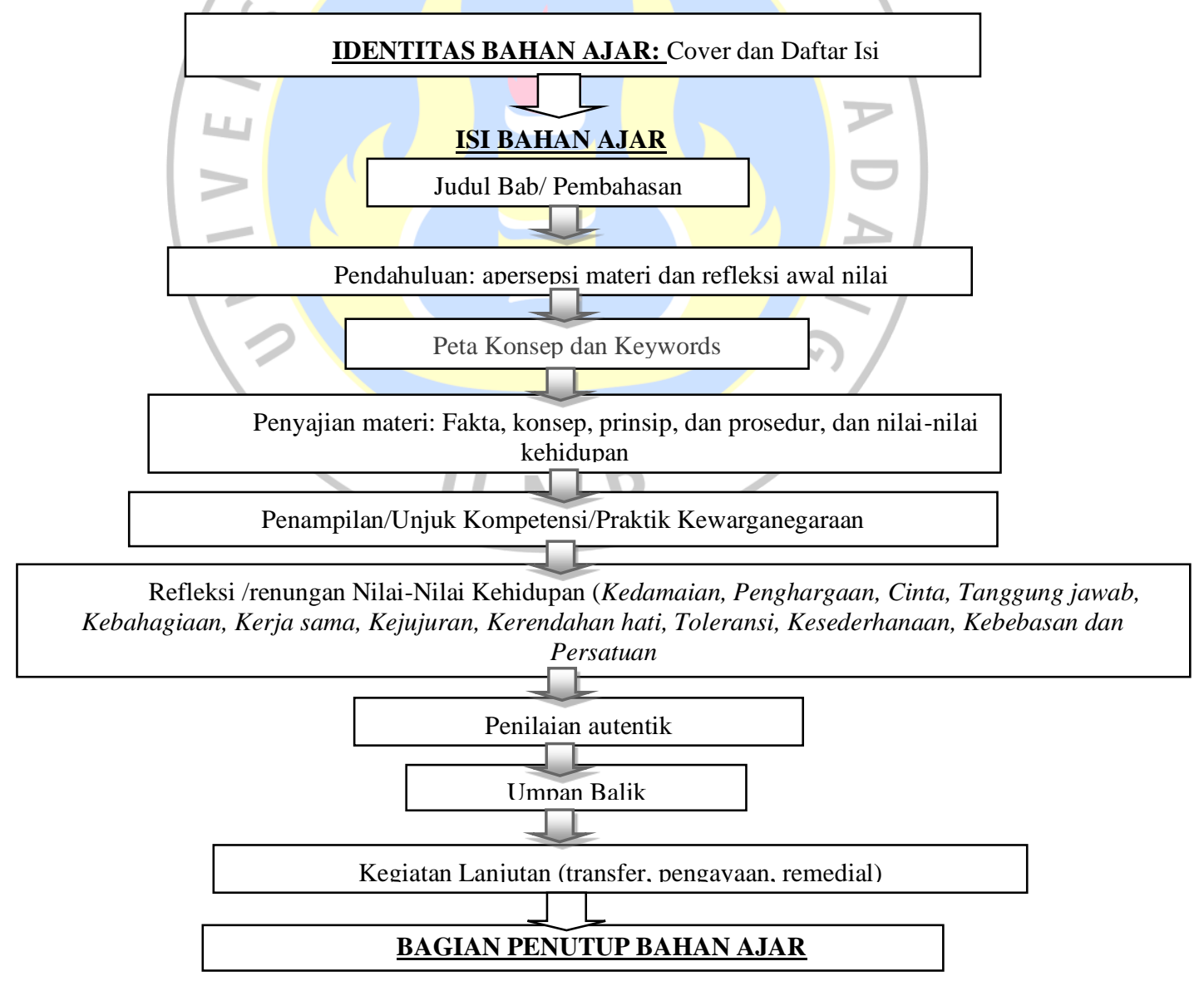

Gambar 1. Kerangka Buku Teks Berbasis Living Values Education (Sumber: Komalasari dkk, 2016) 
Kokom Komalasari, Rahmat Rahmat, Diana Noor Anggraini Model In-On Service Training Pengembangan Bahan Ajar PPKn Berbasis Living Values Education Bagi Guru-Guru PPKn

Berdasarkan konseptual model Bahan Ajar berbasis living values education di atas, maka disusun bahan ajar PPKn dalam sebuah kerangka/outline sebagai berikut:

1) Isi Bahan ajar, meliputi:

a) Judul bab/pembahasan dibuat bermakna (mencerminkan materi dan nilai kehidupan yang hendak dikembangkan)

b) Pendahuluan: diawali dengan sajian gambar, cerita, puisi, kasus, dan lain-lain, diikuti dengan apersepsi pengaitan materi dan refleksi nilai-nilai kehidupan yang akan dikembangkan.

c) Peta konsep dan keyword, merupakan gambaran umum materi yang akan disajikan dan nilai-nilai kehidupan yang akan dikembangkan di dalam bab/pembahasan.

d) Penyajian materi dan klarifikasi nilai-nilai kehidupan, materi yang disajikan di dalam buku meliputi fakta, konsep, prinsip, prosedur, dan nilai-nilai kehidupan (sikap perilaku). Berikut ini gambaran materi yang harus disajikan.

i. Fakta: Menyebutkan nama, kapan, berapa, dan dimana

ii. Konsep: Mendefinisi, mengidentifikasi, mengklasifikasi, menyebutkan ciri-ciri

iii. Prinsip: Pemahaman dan Penerapan dalil, hukum, atau rumus, hipotesis, hubungan antarvariabel.

iv. Prosedur: Pembuatan bagan arus (flowchart), langkah-langkah mengerjakan secara urut.

v. Nilai-nilai kehidupan: Klarifikasi nilai-nilai kehidupan: Kedamaian, Penghargaan, Cinta, Tanggung jawab, Kebahagiaan, Kerja sama, Kejujuran, Kerendahan hati, Toleransi, Kesederhanaan, Kebebasan dan Persatuan.

e) Memancing penampilan/unjuk kompetensi; Siswa diajak untuk melakukan serangkaian tugas praktik kewarganegaraan dalam mengembangkan kompetensi kewarganegaraan (pengetahuan, sikap/nilai/karakter, keterampilan berpikir, dna keterampilan partisipasi).

f) Rangkuman, berisi simpulan materi pembelajaran yang harus dikuasai dan nilai-nilai kehidupan yang harus dikembangkan.

g) Refleksi/Renungan, berisi refleksi terhadap nilai-nilai kehidupan yang dipraktekkan dalam kehidupan sehari-hari melalui Value Clarification Technique (VCT) Daftar. Refleksi dan renungan ini dapat dijasikan sebagai instrument untuk menilai sikap dan perilaku siswa.

h) Penilaian autentik, berisi serangkaian instrument penilaian siswa (tes, skala sikap, dan unjuk kerja)

i) Pemberian umpan balik, berisi kunci jawaban dan format penilaian yang disertai rubrik penilaian.

j) Kegiatan lanjutan (transfer, pengayaan, remedial), berisi arahan kegiatan lanjutan pengayaan materi bagi yang sudah mencapai kompetensi yang diharapkan dan remedial bagi yang belum mencapai kompetensi yang diharapkan.

\subsection{Pelaksanaan Program Pelatihan}

Pada bagian menggambarkan kegiatan pelatihan "Pengembangan Bahan Ajar PPKn berbasis Living Values Education" yang meliputi beberapa tahapan di antaranya: persiapan, pelaksanaan, dan evaluasi yang akan diuraikan berikut ini.

\subsubsection{Persiapan Program}

Kegiatan persiapan dalam pelatihan ini dilakukan melalui beberapa langkah strategis dan sistematis yang disesuaikan dengan bentuk pelatihan "Pengembangan Bahan Ajar PPKn berbasis living values education" sebagai berikut:

\section{Langkah 1: Identifikasi dan Analisis Kebutuhan Pelatihan}

Langkah pertama dan utama dalam pelatihan ini adalah menjajagi dan mengetahui kebutuhan guru terhadap pelatihan bahan ajar inovatif untuk meningkatkan kompetensi pedagogik guru, serta mengetahui sejauh mana kebutuhan tersebut perlu dipenuhi melalui kegiatan pelatihan praktis "Pengembangan Bahan Ajar PPKn Berbasis Living Values Education". 
Kokom Komalasari, Rahmat Rahmat, Diana Noor Anggraini Model In-On Service Training Pengembangan Bahan Ajar PPKn Berbasis Living Values Education Bagi Guru-Guru PPKn

\section{Langkah 2: Pembagian Tugas}

Membagi tugas anggota adalah suatu proses pemilihan tugas dan pembagian tugas yang tepat terkait dalam pelatihan (panitia, fasilitator dan peserta/guru) untuk penyusunan standar-standar tertentu. Secara umum, untuk melakukan analisis jabatan dan analisis tugas dapat dilakukan dengan langkahlangkah sebagai berikut:

a) Menganalisis Uraian Tugas (Job Description)

b) Mengananalisis spesifikasi tugas

c) Menganalisis kualifikasi

\section{Langkah 3: Klasifikasi dan menentukan peserta pelatihan}

Berdasarkan pada tahap tersebut di atas dapat diketahui adanya berbagai klasifikasi peserta, namun yang diambil adalah peserta yang disesuaikan dengan tujuan dan sasaran pelatihan. Maka penentuan peserta diperuntukkan kepada guru-guru SMP, khususnya dalam hal jumlah dengan mempertimbangkan ketersediaan sumberdaya yang mendukung pelatihan.

\section{Langkah 4: Merumuskan Tujuan Pelatihan}

Menentukan tujuan pelatihan bahan ajar PPKn berbasis living values education yang dapat dibedakan dalam tiga kategori pokok domain, yang meliputi:

a) Cognitive Domain, adalah tujuan pelatihan yang berkaitan dengan meningkatkan pengetahuan peserta tentang bahan ajar PPKn berbasis living values education.

b) Affective Domain, adalah tujuan pelatihan yang berkaitan dengan sikap dan tingkah laku dan terhadap bahan ajar PPKn berbasis living values education.

c) Psychomotor Domain yaitu tujuan pelatihan yang berkaitan dengan ketrampilan/skill peserta pelatihan dalam menerapkan bahan ajar PPKn berbasis living values education.

\section{Langkah 5: Rancangan Program Pelatihan}

Langkah-langkah penting di dalam menyusun rancangan program pelatihan sebagai berikut.

a) Menentukan \& Memprioritaskan Isi/Muatan Materi Pelatihan (20\% teori dan $80 \%$ praktek).

b) Membangun Hubungan Logis dan Urutannya

c) Membangun hubungan logis dan urutan materi berdasarkan antar bidang topik/isi; dan hubungan logis dan urutannya berdasarkan pada satu bidang topik/isi yang dipecah menjadi sub topik yang lebih rinci

d) Menentukan Metoda \& Media Pelatihan

Sesuai dengan prinsip pendidikan orang dewasa yang menghendaki adanya keterlibatan aktif peserta pelatihan, maka di dalam menentukan metoda pelatihan, hal yang paling mendasar untuk diperhatikan adalah "adanya keterlibatan maksimal" peserta pelatihan

e) Menentukan Kebutuhan Waktu

Menentukan perkiraan kebutuhan waktu yang didasarkan pada "skala prioritas". Artinya bahwa "topik utama" (penerapan bahan ajar PPKn berbasis living values education) yang menjadi prioritas akan mendapatkan alokasi waktu yang cukup panjang, sedangkan "topik yang lain" (pemahaman konsep bahan ajar PPKn berbasis living values education) memperoleh alokasi waktu yang relatif pendek.

\section{Langkah 6: Rencana Program Pelatihan}

Perencanaan program pelatihan untuk menentukan hal-hal sebagai berikut: Siapa peserta pelatihan dan berapa jumlahnya, siapa fasilitator/pelatih, dimana tempat pelatihan akan dilaksanakan, waktu penyelenggaraan, kelengkapan pendukung, kebutuhan biaya dan menetapkan sumber dana, bahan pelatihan, teknis penyelenggaraan, dan dokumentasi.

\section{Langkah 7: Menyusun dan Mengembangkan Kerangka Acuan (TOR)}

Langkah penting selanjutnya adalah menyusun dan mengembangkan suatu kerangka Acuan Pelatihan atau Terms of Reference (TOR). Pada umumnya garis besar isi Kerangka Acuan Pelatihan (TOR) ini meliputi pokok pokok sebagai berikut: Latar Belakang/Pendahuluan (Mengapa); Tujuan Pelatihan (Untuk Apa); Pokok Bahasan/Materi Pelatihan (Apa); Pendekatan dan Metodologi

$$
\begin{array}{r}
\text { ABDI: Jurnal Pengabdian dan Pemberdayaan Masyarakat Vol. } 3 \text { No. } 1 \\
\text { E-ISSN: 2684-8570| ABDI } 2021 \\
\text { Copyright }{ }^{\complement} 2021 \text {, By Author }
\end{array}
$$


Kokom Komalasari, Rahmat Rahmat, Diana Noor Anggraini Model In-On Service Training Pengembangan Bahan Ajar PPKn Berbasis Living Values Education Bagi Guru-Guru PPKn

Pelatihan (Bagaimana); Peserta Pelatihan dan Fasilitator (Siapa); Waktu dan Tempat Pelatihan (Kapan dan Dimana); dan Sumber dana dan Pembiayaan (Berapa).

\subsection{Pelaksanaan Kegiatan Pelatihan}

Model In-On Service Training terdiri atas kegiatan In-service Training dan On-Service Training. Metode penyampaian materi pelatihan juga dikombinasikan antara pemaparan teori tentang Penelitian Tindakan Kelas dan penerapan teori-toeri tersebut dalam bentuk kegiatan simulasi, latihan, diskusi dan presentasi pada kegiatan In-Service Learning. Kegiatan pelatihan dilakukan dengan tahapan sebagai berikut:

\subsubsection{Kegiatan In-Service Training}

Pada tahap ini dibahas tentang teori bahan ajar PPKn berbasis living values education, yang meliputi: konsep bahan ajar berbasis living values education, pengembangan multimedia pembelajaran berbasis living values education dalam PPKn, dan penggunaannya dalam pembelajaran PPKn. Kegiatan in-service training 1 ini diakhiri dengan membuat Rencana Tindak Lanjut (RTL) tentang pengembangan bahan ajar PPKn berbasis living values education. Pada tahap ini empat orang narasumber akan menyampaikan struktur program kegiatan. Selanjutnya, mengidentifikasi kebutuhan peserta (analisis kebutuhan) dengan memfokuskan pelatihan pada beberapa struktur program yang dibutuhkan oleh peserta. Prosedur rinci pada tahap ini adalah sebagai berikut:

a) Ketika registrasi tim pengabdian memberikan soal pretes kepada peserta melalui google form

b) Tim pengabdian menyampaikan struktur program pelatihan.

c) Tim pengabdian melakukan analisis kebutuhan peserta tentang topik-topik yang ditawarkan pada struktur program.

d) Tim pengabdian menjadi salah satu narasumber dan memulai program melalui zoom meeting serta memfasilitasi kegiatan curah pendapat tentang topik pada struktur program hasil analisis kebutuhan peserta.

e) Narasumber memaparkan materi tentang topik pada struktur program hasil analisis kebutuhan peserta.

f) Narasumber memberikan kesempatan kepada peserta untuk bertanya tentang beberapa hal yang belum dipahaminya.

g) Narasumber mengelompokkan peserta menjadi beberapa kelompok

h) Peserta secara berkelompok berdiskusi untuk mengisi Lembar Kerja (LK).

i) Setiap peserta menyusun Rencana Tindak Lanjut (RTL) untuk tahap On.

\subsubsection{Kegiatan On Service Training}

Peserta mengembangkan bahan ajar PPKn berbasis living values education dengan menerapkan seluruh pengetahuan dan keterampilan yang telah mereka dapatkan selama kegiatan inservice learning 1. Pada tahap ini, peserta akan dibimbing dan dimonitoring pelaksanaan pengembangan bahan ajar PPKn berbasis living values education oleh fasilitator.

Gambaran dari model In-On Service Training dapat dilihat pada gambar di bawah ini.

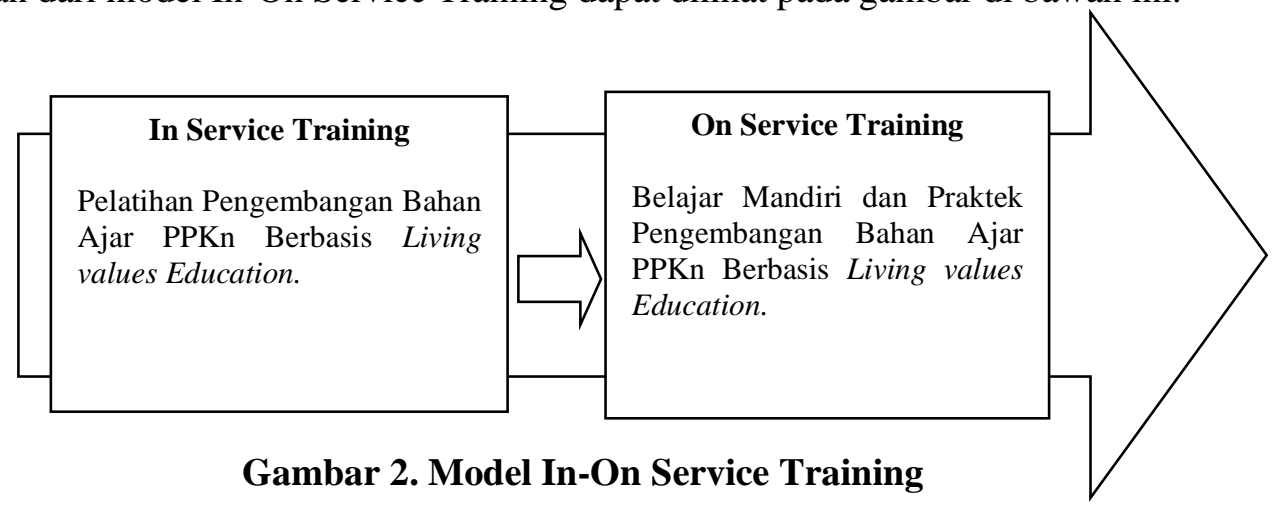


Kokom Komalasari, Rahmat Rahmat, Diana Noor Anggraini Model In-On Service Training Pengembangan Bahan Ajar PPKn Berbasis Living Values Education Bagi Guru-Guru PPKn berikut.

Pelaksanaan kegiatan In-On Service Training ini mengacu kepada prinsip-prinsip sebagai

a) Prinsip perbedaan individu. Memosisikan peserta sebagai individu yang unik. Artinya memiliki sejumlah karakteristik yang berbeda satu sama lain. Karakteristik yang dimaksud berupa kepribadian, latar belakang pendidikan, pengalaman kerja sebagai guru, dan pengalaman hidup sebagai individu.

b) Prinsip motivasi. Memperkuat motivasi peserta untuk belajar bersama dan belajar secara terus menerus serta memperkuat motivasi untuk selalu mengembangkan kompetensi khususnya terkait dengan penerapan pembelajaran secara benar.

c) Prinsip partisipasi aktif. Memartisipasikan peserta secara aktif dalam proses pelatihan.

d) Prinsip seleksi peserta. Peserta haruslah berdasarkan hasil seleksi sesuai dengan kriteria peserta dan memenuhi persyaratan umum dan persyaratan khusus.

e) Prinsip seleksi narasumber. Narasumber haruslah mereka yang sesuai dengan kemampuan profesionalnya dan memenuhi persyaratan umum dan persyaratan khusus.

f) Prinsip andragogik. Memosisikan peserta sebagai orang dewasa yang sedang belajar yang memiliki tingkat kedewasaan.

\subsubsection{Evaluasi Pelatihan}

Kegiatan ini dilakukan untuk kegiatan in-service training maupun on-service training. Evaluasi untuk kegiatan in-service training dilaksanakan menggunakan instrumen evaluasi penyelenggaraan diklat yang dilaksanakan diakhir pelatihan. Instrumen ini digunakan untuk mengukur tingkat releyansi dan efektifitas pelatihan berdasarkan kebutuhan peserta. Hasil evaluasi smiley face ini digunakan untuk bahan melakukan perbaikan pada hari berikutnya. Monitoring dan evaluasi kegiatan ini dilakukan oleh tim PkM berbasis Hasil Penelitian, MGMP PPKn SMP dan Dinas Pendidikan Kota Tasikmalaya dalam rangka mengumpulkan informasi, memberikan pertimbangan dan memutuskan solusi perbaikan untuk kegiatan selanjutnya. Adapun mekanisme monitoring dan evaluasi kegiatan ini diperlihatkan dengan gambar 3 sebagai berikut.

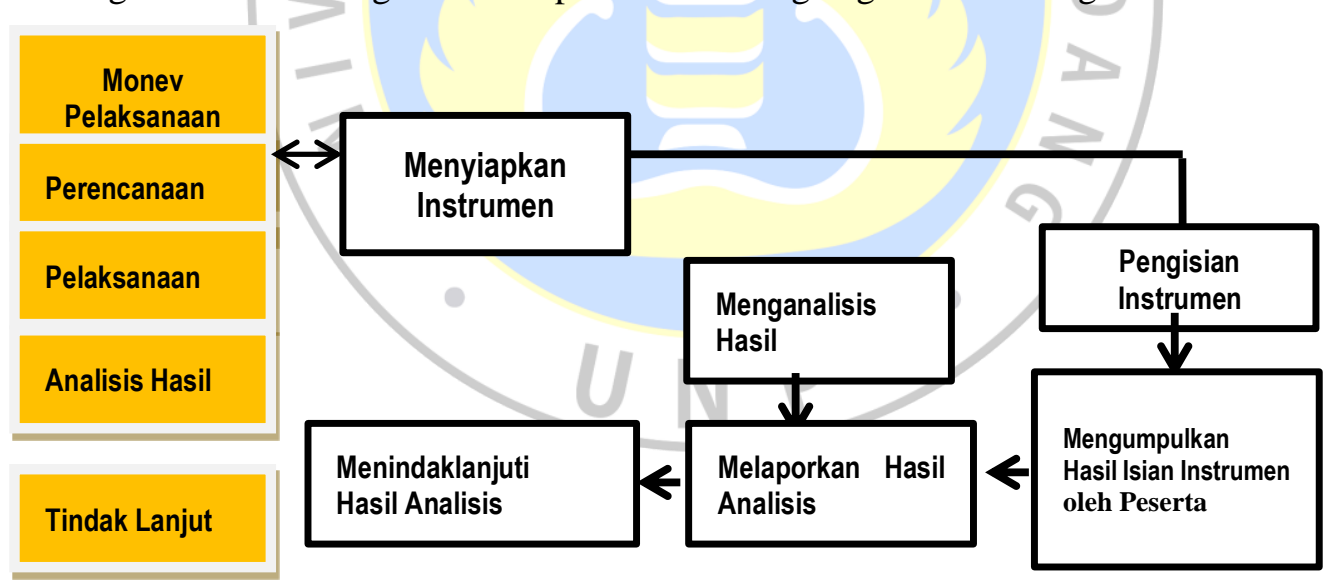

Gambar 3. Monitoring dan Evaluasi Kegiatan In-On Service Training

Mekanisme monitoring dan evaluasi terdiri atas:

a) Kegiatan perencanaan yaitu menyiapkan instrumen monev diantaranya adalah instrumen penilaian kegiatan, instrumen pretes dan postes.

b) Kegiatan pelaksanaan yaitu pengisian instrumen oleh peserta

c) Kegiatan analisis data yaitu mengumpulkan hasil kerja peserta, isian instrumen dan menganalisis hasilnya

d) Kegiatan tindak lanjut yaitu pelaporan hasil analisis dan melakukan tindak lanjut hasil dari analisis. 
Kokom Komalasari, Rahmat Rahmat, Diana Noor Anggraini Model In-On Service Training Pengembangan Bahan Ajar PPKn Berbasis Living Values Education Bagi Guru-Guru PPKn

\section{Kesimpulan}

Pelatihan bahan ajar berbasis living values education dilaksanakan secara daring. Beberapa diskusi dilakukan membahas hasil penelitian yang pernah dilakukan peneliti sebelumnya dan diaplikasikan oleh guru-guru di sekolah. Berdasarkan hasil penelitian Komalasari dkk. (2011-2018), khususnya dalam pengembangan bahan ajar PPKn berbasis living values education sebagai salah satu komponen pembelajaran yang memiliki peranan penting. Pengembangan bahan ajar PPKn berbasis living values education tidak akan dapat dilepaskan dari praktek model pembelajaran, sehingga dalam sajian ini dibahas hasil penelitian terkait dengan model pembelajaran berbasis living values education dan hasil penelitian bahan ajar PPKn berbasis living values education untuk pengembangan karakter peserta didik. Adapun prinsip penulisan bahan ajar berbasis living values education; 2) Mengembangkan prinsip-prinsip living values education; 3) Menerapkan prinsip pembelajaran dalam penulisan bahan ajar; 4) Mengembangkan kompetensi inti dan kompetensi dasar dalam kurikulum 2013; 5) Memperhatikan prinsip-prinsip penyusunan materi/bahan ajar; 6) Bahasa dan keterbacaan disusun dengan memenuhi kriteria EYD, dan 7) Penampilan bahan ajar (Grafika) dibuat menarik. Kegiatan pelatihan "Pengembangan Bahan Ajar PPKn berbasis Living Values Education" yang meliputi beberapa tahapan di antaranya: persiapan, pelaksanaan, evaluasi dan tindak lanjut yang akan diuraikan berikut ini.

\section{Daftar Pustaka}

Balchin, N., Randall, L., \& Tunner, S. (2006). The couch consult methods: A model for a sustainable change in schools. Educational Psychology in Practice, 22(3), 237-254.

CERI. (1982). In-service education and training of teachers: A condition for educational change. Paris: OECD.

Clark, N. (1991). Managing Personal Learning and Change, A Trainer's Guide. London: McGrawHill Book Company.

Komalasari, K., Abdulkarim, A., \& Saripudin, D. (2018). Culture-Based Social Studies Learning Model in Developing Student Multiculturalism. The New Educational Review, 51(1), 173183.

Komalasari, K., Bestari, P., \& Haryasa, Y. (2012). ). Pengembangan Karakter Siswa SMP melalui Model Pembelajaran Kontekstual Berbasis Living Values Activity. Bandung.

Komalasari, K., \& Saripudin, D. (2017). Value-Based Interactive Multimedia Development through Integrated Practice for The Formation of Students' Character. Turkish Online Journal of Educational Technology, 16(4), 179-186.

Komalasari, K., Saripudin, D., \& Iswandi, D. (2016). Pengembangan Multimedia Interaktif Berbasis Nilai melalui Practical Integrated untuk Pembentukan Karakter Mahasiswa. Bandung.

Komalasari, K., Saripudin, D., \& Masyitoh, I. . (2015). Pengembangan Model Buku Teks PPKn SMP Berbasis Living Values Education untuk Pembenetukan Karakter Peserta Didik. Bandung.

Komalasari, K., Saripudin, D., \& Masyitoh, I. . (2016). Pengembangan Model Buku Teks PPKn SMP Berbasis Living Values Education untuk Pembenetukan Karakter Peserta Didik. Bandung.

Komalasari, K., Saripudin, D., \& Masyitoh, I. S. (2013). Pengembangan Living Values Education dalam Pembelajaran, Habituasi, dan Ekstrakurikuler untuk Pembentukan Karakter Peserta Didik. Bandung.

Komalasari, K., Saripudin, D., \& Masyitoh, I. S. (2014). Pengembangan Living Values Education dalam Pembelajaran, Habituasi, dan Ekstrakurikuler untuk Pembentukan Karakter Peserta Didik. Bandung.

Komalasari, K., \& Syaifullah, S. (2011). Model Pembelajaran Kontekstual berbasis Living Values Activity untuk Pengembangan Karakter Mahasiswa. Bandung.

Mirici, I. . (2006). Electronic in-service teacher-training for the new national EFL curriculum in Turkey. Turkish Online Journal of Distance Education-TOJDE, 7(1), 155-164. 
Kokom Komalasari, Rahmat Rahmat, Diana Noor Anggraini Model In-On Service Training Pengembangan Bahan Ajar PPKn Berbasis Living Values Education Bagi Guru-Guru PPKn

Pemerintah Daerah Kota Tasikmalaya. (2017). Kabupaten Tasikmalaya dalam Angka. Tasikmalaya: Pemerintah Daerah Kabupaten Tasikmalaya.

Pike, B. (2005). The More Effective Alternative to Lecture-Based Training. Retrieved from http://www.bobpikegroup.com/seminars/whatis_pct.html

Robinson, D. G., \& Robinson, J. C. (1989). Training for Impact: How to Link Training to Business Needs and Measure The Results. California: Jossey-Bass Inc., Publishers.

Tillman, D. (2004). Living Values: Avtivities for Children Ages 8-14. Jakarta: PT. Gramedia.

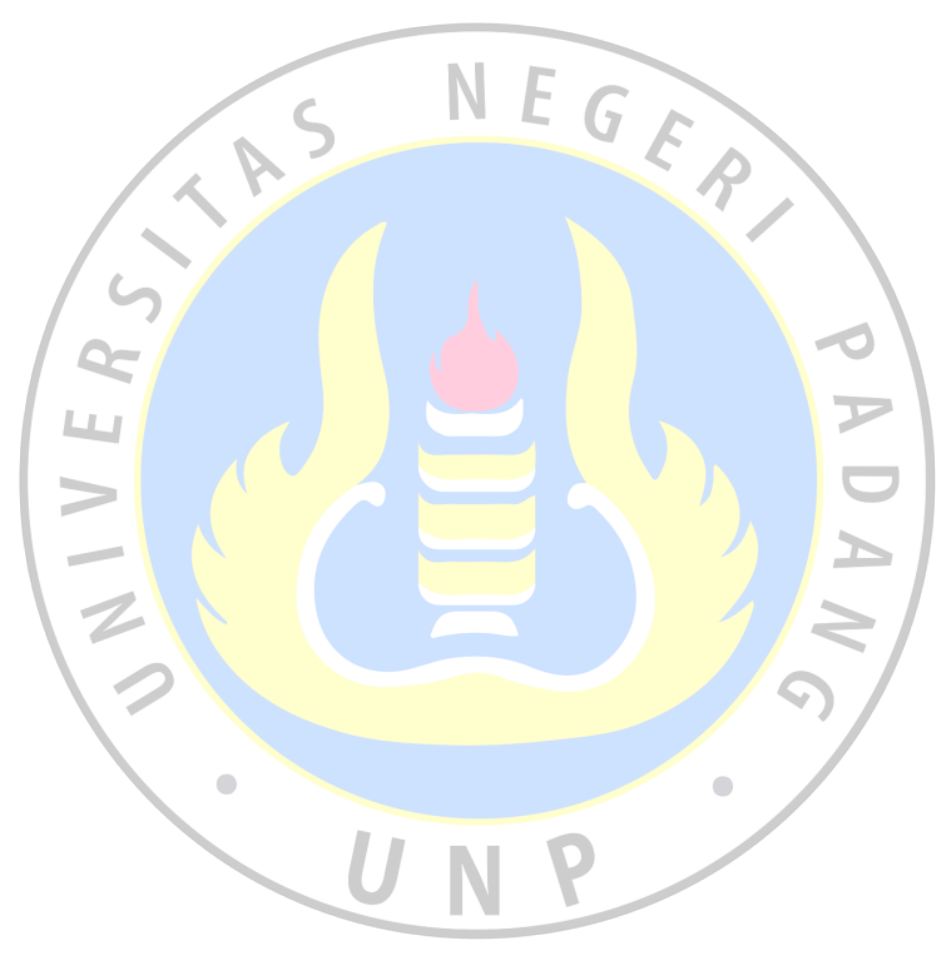

